\title{
PLANT COMMUNITY CHANGES FOLLOWING CLOSURE OF ARTESIAN WELLS IN GREAT SAND DUNES NATIONAL PARK, COLORADO
}

\author{
Sarah J. Garza ${ }^{1,3}$, Gillian Bowser ${ }^{2}$, and Kenneth R. Wilson ${ }^{1}$
}

\begin{abstract}
AвstRACT.-Artificial artesian wells have existed in the San Luis Valley of south central Colorado for over 100 years, and they are an important source of water for livestock and wildlife. When Great Sand Dunes National Park and Preserve (GRSA) expanded its boundaries in 2000, ten of these wells were within the new park boundary. Because the habitat surrounding the wells was so severely disturbed by cattle and wildlife trampling, the National Park Service capped the wells in 2010 to promote restoration of the areas to a more natural state. To study changes after well-capping, we compared the plant communities in 2011 and 2012. We measured and compared plant cover, species frequency, and species diversity at recently capped wells on GRSA, at flowing wells (i.e., with water) on adjacent private lands of The Nature Conservancy, and at reference sites. In general, there was little difference in percentage of plant cover and species diversity between well types. For percent cover, annual variation and distance from wellheads were the best predictors for the native and exotic plant species, respectively. Plant species composition varied by well type, with reference sites having the greatest frequency of native plants per site and capped well sites having the greatest frequency of exotic plants per site. For native plants, reference sites had the highest species diversity, while capped wells had the highest community evenness. Overall, our results suggest that in the short term, native plant populations have changed little after well-capping, but the frequency of exotic plants has increased at capped well sites relative to reference sites.
\end{abstract}

Resumen.-Los pozos artesianos artificiales han existido en el Valle de San Luis en el centro sur de Colorado durante más de 100 años, y son una importante fuente de agua para el ganado y la vida silvestre. Cuando la Reserva Natural y Parque Nacional Great Sand Dunes (GRSA) expandió sus límites en el año 2000, 10 pozos artesianos estaban dentro de los límites del nuevo parque. En 2010, el Servicio del Parque Nacional tapó esos pozos para restaurar el hábitat circundante y llevarlo a un estado más natural, que había sido severamente dañado por el paso del ganado y la fauna silvestre. Para estudiar los cambios después que los pozos fueron tapados, comparamos las comunidades de plantas en 2011 y 2012. Medimos y comparamos la cobertura vegetal, la frecuencia de especies y la diversidad de especies en pozos recientemente tapados en el GRSA, en pozos florecientes (es decir, con agua), en tierras privadas adyacentes a The Nature Conservancy y en lugares de referencia. En general, había poca diferencia en el porcentaje de la extensión y la diversidad de plantas entre los dos tipos de pozos. Para el porcentaje de la cobertura, las variaciones anuales y la distancia desde la boca del pozo fueron los mejores indicadores para las especies de plantas tanto nativas como exóticas, respectivamente. La composición de especies de plantas variaban por el tipo de pozo con los lugares de referencia teniendo la mayor frecuencia de plantas nativas por lugar, y los sitos de pozos tapados tenían la mayor frecuencia de plantas exóticas por lugar. Para las plantas nativas, los lugares de referencia tenían la diversidad de especies más alta, mientras que los pozos tapados tenían la uniformidad de comunidades más alta. Nuestros resultados sugieren que, a corto plazo, las poblaciones de plantas nativas han cambiado poco después del tapado de los pozos, pero la frecuencia de plantas exóticas ha aumentado en lugares con pozos tapados en relación con los lugares de referencia.

We evaluated changes in plant communities around historic artesian wells following capping at sites in the Great Sand Dunes National Park and Preserve (GRSA) and compared the plant communities at capped sites to those at flowing well sites in adjacent private lands of The Nature Conservancy. Located in south central Colorado, the GRSA provides a unique opportunity to study the removal of artificial sources of water in an arid ecosystem. Prior to the establishment of Great Sand Dunes National Monument in 1932, this area was developed for ranching operations, and 24 artificial artesian wells were drilled into the underlying confined aquifer to provide water for local cattle herds. Areas around these well sites were highly disturbed from frequent visitation by cattle and wild ungulates, such as elk (Cervus elaphus) and, more recently, bison (Bison bison). When Great Sand Dunes became a national park, all artesian wells on National Park Service lands (10) were capped in 2010, while 14 well sites on adjacent lands owned by The Nature Conservancy remained flowing. Along

\footnotetext{
${ }^{1}$ Department of Fish, Wildlife, and Conservation Biology, Colorado State University, Fort Collins, CO 80523.

${ }^{2}$ Natural Resources Ecology Laboratory, Colorado State University, Fort Collins, CO 80523.

${ }^{3}$ E-mail: sarah.garza@rams.colostate.edu
} 
with maintaining the natural hydrological system of the sand dunes, the National Park Service is interested in eliminating the piosphere effect (highly-denuded zones of landscape around an artificial water source; Lange 1969), thereby restoring the ecosystem to a more natural state. We studied changes at artesian well sites following capping by studying disturbance regimes and plant community composition.

An important component of the GRSA is the local plant community. Artificial water sources can impact plant communities by increasing water availability, which can alter forage abundance and concentrate livestock and wildlife (Andrew 1988, Brooks et al. 2006). The resulting combination of trampling, grazing, and high densities of ungulates, especially in arid ecosystems, can produce a gradient of disturbance, with the greatest intensity nearest to the water source (Nash et al. 1999). Piosphere plant communities are usually distinguished by early stages of ecological succession (e.g., large areas devoid of plant cover; Andrew and Lange 1986, Fusco et al. 1995), decreased plant species composition (Tolsma et al. 1987, Fernandez-Gimenez and AllenDiaz 2001), and decreased plant reproductive output (Riginos and Hoffman 2003). Although recent research on artificial water sources has focused on stream recovery (Rigge et al. 2013) and soil conditions in relation to grazing intensity (Augustine et al. 2012), few studies have examined the effects of removal of water sources. This knowledge is important for managing our natural resources, especially in light of climate change and predicted drought increase in some areas (Cayan et al. 2010).

Based on observations of increased native plant growth near areas of intermediate disturbance at artificial water sites (Nash et al. 1999, Brooks et al. 2006), we hypothesized that plant population dynamics would be related to ungulate disturbance intensity levels. Capping the artesian wells reduced disturbance, which subsequently improved habitat, and resulted in the following patterns of native plant cover and community diversity indices: capped well sites $>$ reference sites $>$ flowing well sites. Our work provides park resource managers with an initial glimpse into the restoration dynamics surrounding these artificial water sources, and this report may also be useful to other land and resource managers interested in similar restoration efforts.

\section{Methods}

We collected data from May to August in 2011 and 2012 within GRSA and the adjacent Zapata Ranch (ZR) owned by The Nature Conservancy. The study area is within the San Luis Valley, a high-elevation $(2000 \mathrm{~m}$ above sea level) closed basin valley near the New Mexico state line (Fig. 1). The valley is semiarid, with annual October-March and JulySeptember precipitation of 104 and $28 \mathrm{~cm}$, respectively, and annual winter and summer temperatures ranging from -9.5 to $1.5^{\circ} \mathrm{C}$ and 26.5 to $29.5{ }^{\circ} \mathrm{C}$ (Western Regional Climate Center [accessed 20 March 2013]: http://www .wrcc.dri.edu). The valley is characterized by high elevation and semiarid shrubland mixed with areas of loose sand and sand sheets. Key grasses included blue grama (Bouteloua gracilis), Indian ricegrass (Oryzopsis hymenoides), needle and thread (Hesperostipa comata), and false buffalograss (Munroa squarrosa). Key shrubs were rubber rabbitbrush (Ericameria nauseosus), sagebrush (Artemisia spp.), and yucca (Yucca glauca). Exotic plants included Russian thistle (Salsola tragus), Russian knapweed (Acroptilon repens), and cheatgrass (Bromus tectorum) (Spackman Panjabi et al. 2004).

Large mammals in the valley include native ungulates such as bison, elk, pronghorn antelope (Antilocapra americana), and mule deer (Odocoileus hemionus). Cattle were introduced in the late 1840s, areas of the valley were fenced, and native ungulates were removed (Swift 1945, Schoenecker 2012). Cattle grazing within GRSA ceased in 2004, and currently, elk, mule deer, and pronghorn antelope have repopulated the area. Approximately 2000 bison are within fenced areas on the ZR (Zapata ranch website [accessed 31 October 2013]: http://www.zranch.org/index.cfm?id=78c5928 2-b953-4aa0-bf4ec2b2e24c4d76\&history-ofthe-ranch.html). Elk, mule deer, and pronghorn antelope move freely across the GRSA and ZR fenced and unfenced areas, but there are no free-ranging bison in the GRSA.

We selected 2 capped well sites on the GRSA, 2 flowing well sites on the ZR, and 2 reference sites, one within the GRSA and one within the ZR. We centered our sampling on the well at well sites or on the geographic center at reference sites and compared percent plant species cover, frequency of occurrence (hereafter referred to as "frequency"), 


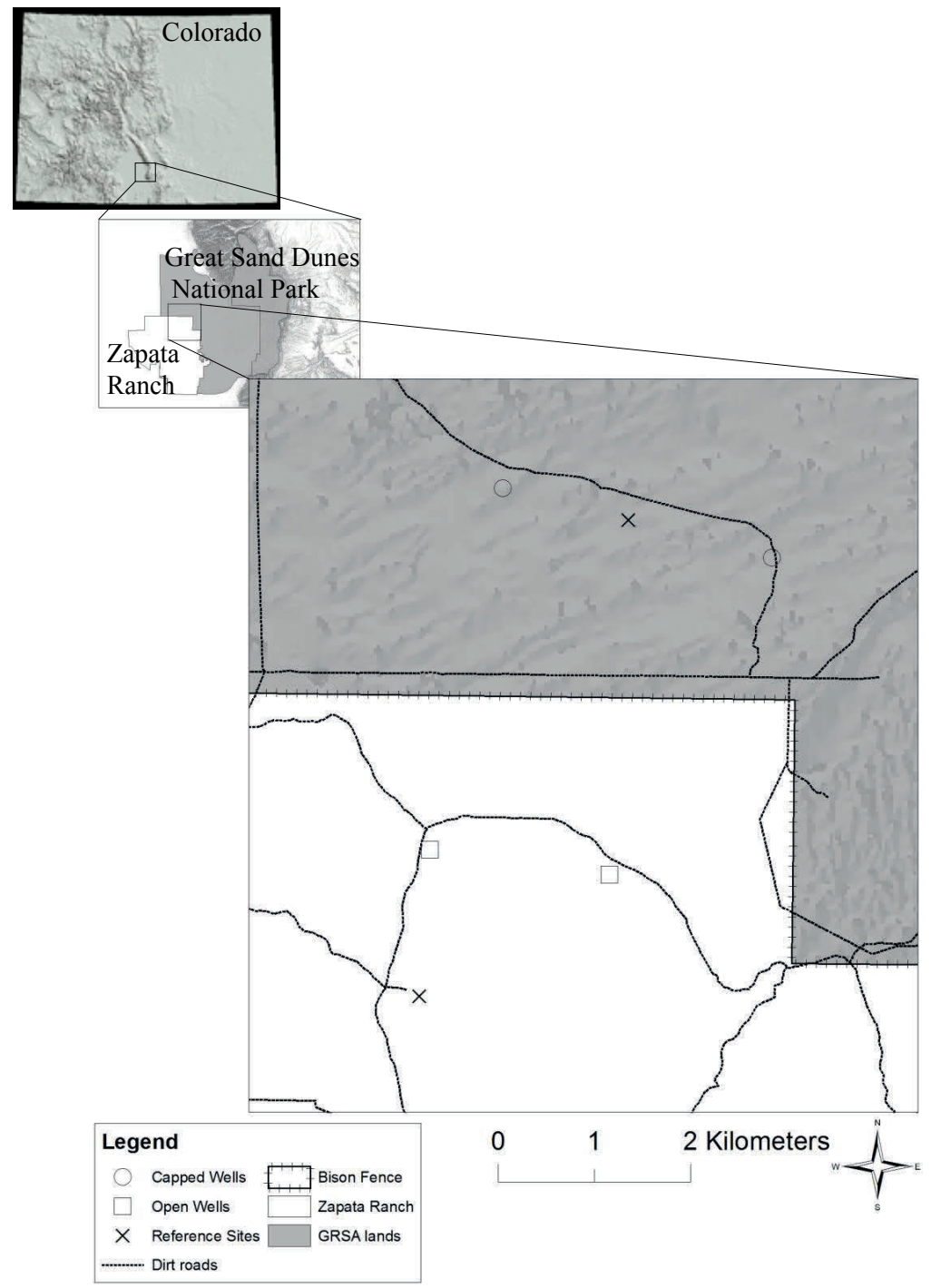

Fig. 1. Location of well sites and reference sites studied in Great Sand Dunes National Park and Preserve and The Nature Conservancy's Zapata Ranch, Colorado, 2011-2012 (Image of Colorado [accessed 2 December 2013]: http://www.colorado.gov/cs/Satellite/DOLAMain/CBON).

and species diversity. Wells consisted of steel pipes inserted into the ground that filled a tank made of metal or a large tire. Flowing wells (Fig. 2A) had less vegetation around the tanks compared to capped wells (Fig. 2B), and all wells had established piosphere conditions prior to the study. At each study area, 12 lines of $100 \mathrm{~m}$ were established, radiating from a central point offset $10 \mathrm{~m}$ north of the wellhead to avoid any tank structures. Vegetation sampling points were established at 10 -m intervals along each line $(n=120$ per site). If the sample point was directly on a road or an obstruction, the sampling frame was relocated along the transect line and the new position was recorded. All sampling locations were staked, flagged, and labeled with the distance from center and the transect number.

Plant cover $(0 \%-100 \%)$ was estimated at all sites between late May and late August during 3 monthly sampling periods in 2011 and 4 in 2012. The percentage of native and exotic plant cover, number of individual native and exotic plants (frequency), and ungulate disturbance 

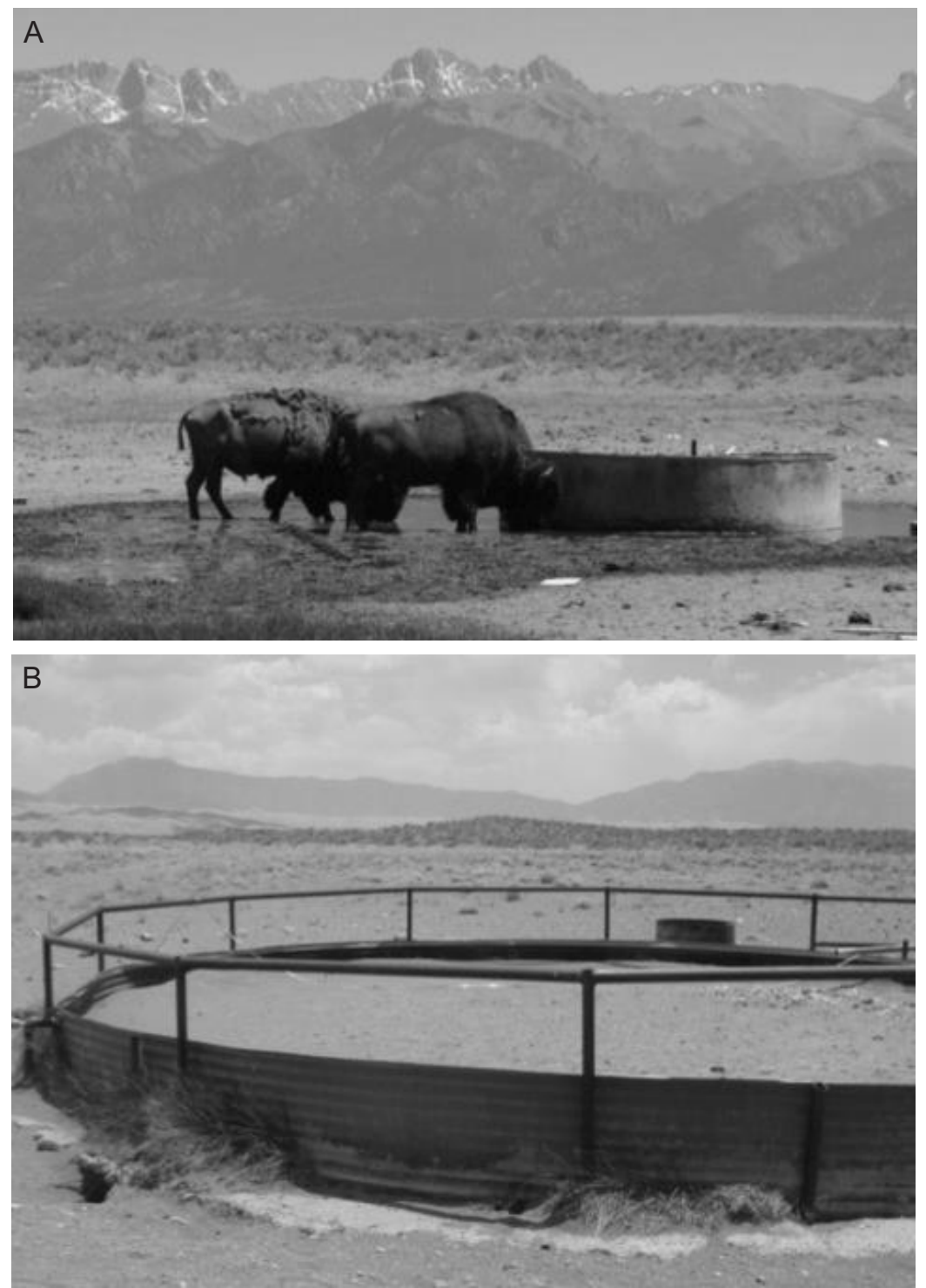

Fig. 2. Typical artesian well sites in 2011 from (A) a flowing well on The Nature Conservancy's Zapata Ranch, Colorado, and (B) a capped well site in Great Sand Dunes National Park and Preserve, Colorado (photographs by Sarah J. Garza).

level were sampled using a $1-\mathrm{m}^{2}$ sampling frame placed at the 10-m intervals along each transect line. Disturbance was categorized as lack of plant cover, compacted sand, presence of tracks (mostly large ungulates), and flattened shrubs. Disturbance intensity within the sampling frame was classified into 4 levels: (0) none, (1) mild (bare ground/trampled area was $<25 \%$ of quadrat), (2) intermediate (bare ground/trampled area was $\sim 50 \%$ of quadrat), and (3) extreme (bare ground/trampled area was $>50 \%$ of quadrat).

Cover and frequency samples $(n=240 ; 2$ sites per well type $\times 120$ quadrats per site) were averaged across distances from the wellhead for each well type, and a square-root transform was applied to normalize variances. Average plant cover and frequency (native and exotic) were modeled as a function of well site type, disturbance intensity level, distance from wellhead, and year of study (2011 or 2012) by 
TABLE 1. Characteristics of plant species (average monthly percent cover and frequency sampled from May to August in 2011 and 2012; $n=7$ ) within $1-\mathrm{m}^{2}$ plots in Great Sand Dunes National Park and Preserve and The Nature Conservancy's Zapata Ranch, Colorado. Sampling occurred at 2 capped well sites (capped since 2010), 2 flowing well sites (artesian well sites still containing water), and 2 reference sites (no artesian wellhead influence). Standard errors are in parentheses.

\begin{tabular}{|c|c|c|c|c|c|}
\hline \multirow[b]{2}{*}{ Year } & \multirow[b]{2}{*}{ Study site } & \multicolumn{2}{|c|}{ Native } & \multicolumn{2}{|c|}{ Exotic } \\
\hline & & Percent cover & Frequency & Percent cover & Frequency \\
\hline \multirow[t]{3}{*}{2011} & Capped well sites & $15.58(0.59)$ & $9.15(0.97)$ & $5.01(0.73)$ & $1.07(0.33)$ \\
\hline & Flowing well sites & $14.13(0.77)$ & $8.43(1.18)$ & $3.93(0.32)$ & $0.69(0.26)$ \\
\hline & Reference sites & $14.95(0.82)$ & $16.73(0.76)$ & $3.00(0.58)$ & $0.02(0.01)$ \\
\hline \multirow{3}{*}{2012} & Capped well sites & $9.53(0.36)$ & $9.84(0.19)$ & $4.95(0.47)$ & $1.30(0.07)$ \\
\hline & Flowing well sites & $9.08(0.27)$ & $8.37(0.34)$ & $2.80(0.29)$ & $1.01(0.06)$ \\
\hline & Reference sites & $9.21(0.39)$ & $16.61(0.23)$ & $1.67(0.13)$ & $0.31(0.08)$ \\
\hline
\end{tabular}

using Proc GENMOD (SAS software, Version 9.1.3, SAS Institute, Inc. 2005). We used $\mathrm{AIC}_{c}$, the small sample size adjustment for AIC (Akaike 1973, Hurvich and Tsai 1989), for model selection (Burnham and Anderson 2002) and computed relative importance values (the sum of the weights, $w+$, over all models in a balanced model set that include the given variable) for each variable.

Species diversity was calculated by the Shannon-Weiner diversity index $\left(H^{\prime}\right)$ using plant cover $(\%)$ as a measure of the relative abundance of species in the sample (Stohlgren 2007). We also calculated the Simpson's diversity index $\left(D^{\prime}\right)$ as a diversity value weighted towards the most abundant species in the sample and used a modified Hill's ratio $\left(E^{\prime}\right)$ as an index of plant species evenness (Hill 1973, Stohlgren 2007).

\section{Results}

Average disturbance intensity was greatest at flowing well sites for both years of the study (2.04 [SE 0.08] in 2011; 2.07 [0.08] in 2012) followed by capped well sites (1.09 [0.6] in 2011; 1.47 [0.07] in 2012), and reference sites (0.4 [SE 0.04] in 2011;0.91 [0.07] in 2012). Capped well sites had the greatest average monthly cover of native plant species per quadrat, followed by reference sites and then flowing well sites in both 2011 and 2012 (Table 1). However, percent native plant cover was not significantly different between site types $\left(F_{2,18}=0.02, P=0.98\right)$. The pattern for exotic species from greatest to lowest average plant cover was capped wells, flowing wells, and reference sites for each year, but the pattern was not significantly different between site types $\left(F_{2,18}=0.53, P=0.59\right)$.
Flowing wells had all identified exotic species present, while capped wells and references sites had only Russian thistle and mat amaranth (Amaranthus blitoides). For both years of the study, native plant frequencies were greatest at reference sites, followed by capped wells and then flowing wells, whereas exotic plant frequencies were greatest at the capped well sites. Frequencies of native plants at the reference sites were significantly greater than at capped wells $\left(t_{6}=5.74, P=0.03\right)$ and flowing wells $\left(t_{6}=6.36, P=0.01\right)$, but frequencies of nonnative plants failed to differ significantly between site types $(P>$ $0.13)$.

Well site type was not in the top-ranked models explaining plant cover for native or exotic species (Table 2). The top-ranked model for native plant cover included only year and had twice the support as the next 2 models, year + distance to wellhead and year + disturbance level. Year of study had the greatest relative importance for native plant cover $(w+$ $=0.99 ; \hat{\beta}=-0.85$ [95\% CI: $-1.28,-0.41]$ ). For exotic plant cover, the top-ranked model included only distance to wellhead and had twice the support as the next 2 models (Table 2 ). Distance to wellhead also had the greatest relative importance $(w+=0.77 ; \hat{\beta}=-0.008$ $[-0.016,-0.001])$.

The 2 top explanatory models for plant frequency of native plants included well site type, along with year of study and distance to wellhead (Table 3), and well site type had the greatest relative importance $(w+=0.99$; capped wells: $\hat{\beta}=-1.37$ [95\% CI: -2.05 , $-0.70]$, flowing wells: $\hat{\beta}=-1.88$ [-2.54, -1.23], reference sites: $\hat{\beta}=6.2[5.70,6.70])$. For exotic plant frequency, the top-ranked models included well site alone or well site with distance to 
TABLE 2. Top model rankings based on $\mathrm{AIC}_{c}$ for a regression of native or exotic plant cover as a function of well site type (capped wells, flowing artesian wells, or reference sites), disturbance intensity level, distance from wellhead, and year of study in Great Sand Dunes National Park and Preserve and The Nature Conservancy's Zapata Ranch, Colorado, 2011-2012.

\begin{tabular}{lcccc}
\hline Model & $\mathrm{AIC}_{c}$ & $\Delta \mathrm{AIC}_{c}$ & $w_{i}$ & $\mathrm{~K}$ \\
\hline Native cover & & & & 0.40 \\
$\quad$ Year & 951.37 & 0 & 0.19 & 2 \\
$\quad$ Year + Distance & 952.84 & 1.47 & 0.17 & 3 \\
Year + Disturbance & 953.09 & 1.72 & 3.07 & 4 \\
$\quad$ Year + Distance + Year* Distance & 954.47 & & \\
Exotic cover & & & \\
Distance & 388.42 & 0 & 0.30 & 2 \\
Year + Distance & 390.00 & 1.58 & 0.13 & 3 \\
Distance + Disturbance & 390.46 & 2.04 & 0.11 & 3
\end{tabular}

aHeadings are Akaike's information criterion for small sample size $\left(\mathrm{AIC}_{c}\right)$, change in $\mathrm{AIC}_{c}\left(\Delta \mathrm{AIC}_{c}\right)$, model weight $\left(w_{i}\right)$, and number of parameters $(\mathrm{K})$ for the most parsimonious models.

TABLE 3. Top model rankings based on $\mathrm{AIC}_{c}$ for a regression of native or exotic plant frequency as a function of well site type (capped wells, flowing artesian wells, or reference sites), disturbance intensity level, distance from wellhead, and year of study in Great Sand Dunes National Park amd Preserve and The Nature Conservancy's Zapata Ranch, Colorado, 2011-2012.

\begin{tabular}{llccc}
\hline Model & \multicolumn{1}{c}{$\mathrm{AIC}_{c}$} & $\Delta \mathrm{AIC}_{c}$ & $w_{i}$ & $\mathrm{~K}$ \\
\hline Native frequency & & & & \\
$\quad$ Well Site + Year + Distance & 1084.27 & 0 & 0.59 & 4 \\
$\quad$ Well Site + Year & 1085 & 0.73 & $1.77 \mathrm{E}-05$ & 3 \\
$\quad$ Disturbance + Year & 1105.10 & 20.83 & 0.41 & 2 \\
Exotic frequency & 410.19 & 0 & 0.29 & 3 \\
$\quad$ Well Site & 410.87 & 0.68 & 0.15 & 3 \\
$\quad$ Well Site + Distance & 412.25 & 2.06 & & 3 \\
Well Site + Year & & & & \\
\end{tabular}

aHeadings are Akaike's information criterion for small sample size $\left(\mathrm{AIC}_{c}\right)$, change in $\mathrm{AIC}_{c}\left(\Delta \mathrm{AIC}_{c}\right)$, model weight $\left(w_{i}\right)$, and number of parameters $(\mathrm{K})$ for the most parsimonious models.

TABLE 4. Native plant species richness and diversity indices at capped well sites, flowing well sites, and reference sites in Great Sand Dunes National Park and The Nature Conservancy's Zapata Ranch, Colorado, 2011-2012. Standard errors are in parentheses. ${ }^{\mathrm{a}}$

\begin{tabular}{llllll}
\hline Year & \multicolumn{1}{c}{ Study site } & Species richness & $H^{\prime}$ & $D^{\prime}$ & $E^{\prime}$ \\
\hline 2011 & Capped well sites & $11(0)$ & $3.24(0.04)$ & $0.86(0.004)$ & 0.13 \\
& Flowing well sites & $11(0)$ & $3.66(0.03)$ & $0.89(0.002)$ & 0.02 \\
2012 & Reference sites & $11.5(0.71)$ & $3.69(0.03)$ & $0.96(0.001)$ & 0.09 \\
& Capped well sites & $27(1.71)$ & $4.08(0.02)$ & $0.92(0.001)$ & 0.08 \\
& Flowing well sites & $26(1.23)$ & $4.12(0.02)$ & $0.93(0.001)$ & 0.06 \\
& Reference sites & $31.5(1.71)$ & $4.41(0.02)$ & $0.95(0.0004)$ & 0.04 \\
\hline
\end{tabular}

aHeadings are Shannon-Weiner diversity index $\left(H^{\prime}\right)$, Simpson diversity index $\left(D^{\prime}\right)$, and modified Hill's ratio $\left(E^{\prime}\right)$.

wellhead and year of study. Well site type had the greatest relative importance $(w+=0.99$; capped wells: $\hat{\beta}=1.20[0.65,1.74]$, flowing wells: $\hat{\beta}=1.18[0.62,1.74]$, reference sites: $\hat{\beta}=1.19[0.82,1.57]$.

Native species richness was greatest at reference sites during both years of the study (Table 4). The pattern for species diversity indices (Shannon-Weiner and Simpson) by year was reference sites $>$ flowing well sites $>$ capped well sites, whereas evenness was greatest at capped well sites.

\section{Discussion}

Capping artesian well sites resulted in decreased disturbance of the surrounding habitat, but capping did not result in greater native plant cover, frequency, or species diversity. Instead, native cover varied more by year of the study, suggesting that annual variation in precipitation may have played a more important role over the 2 years of our study. Plant communities in shrub-dominated western North America evolved with little influence 
of large native ungulates (Mack and Thompson 1982) and, as a result, are poorly adapted to recover from frequent disturbances, especially the intensity of disturbance around well sites (Brooks et al. 2006). Indeed, native plant frequency and diversity were generally greatest at reference sites, which had the least amount of disturbance compared to flowing and capped well sites. Capped well sites had less disturbance than flowing wells, but the lack of difference between the plant communities of these well types suggests that recovery time may take many years. The lengthy recovery will likely result from the lower native plant frequency and diversity, with capped wells being a remnant of the cumulative effects of disturbance over decades. In addition, the amount of disturbance at artesian wells in our study might be more severe in comparison to other studies. For example, Golodets et al. 2010 found 3 years of grazing exclusion to be sufficient for recovery of biomass production in an arid grassland system, while similar recoveries in vegetation composition have been documented 3-10 years after disturbances were removed in other grassland systems (Gutman and Seligman 1979, Milchunas 2011).

We found greater plant cover and frequency of exotic species at capped well sites than at flowing wells and reference sites. Abundance of exotics at artificial water sites has been noted in several studies (Andrew and Lange 1986, James et al. 1997, Nangula and Oba 2004, Todd 2006), and we hypothesize that the greater disturbance at flowing well sites suppressed exotic growth and that capped well sites, which still had a large amount of disturbance but less than flowing wells, is where exotics have opportunity to emerge. In piospheres among sagebrush communities in Idaho, the exotic cheatgrass overwhelmed the local ecosystems (Hosten and West 1994), and in Australian rangelands, exotic plant cover increased with proximity to water sites (Landsberg et al. 2003).

Drought conditions are not uncommon in the sand sheet habitat of the GRSA (Marin et al. 2005), and our study area experienced lower-than-average precipitation in both years of this study (Western Regional Climate Center [accessed 20 March 2013]: www.wrcc.dri.edu). Such conditions can also favor exotic plants, which are resilient to drought conditions and can dominate water-stressed, arid ecosystems (Kotanen 1997, Marushia et al. 2012, Perry et al. 2013). Even the establishment of a diverse native plant community at previously disturbed sites does not necessarily limit the distribution of exotic species (Lonsdale 1999).

The recovery of arid grasslands from a long-term disturbance can take decades (Daubenmire 1975, Rickard and Sauer 1982), and our data suggests that, in the short term, capping of artesian wells has not resulted in a complete recovery of the well sites, where recovery is defined as a return to reference site conditions. The artesian wells in our study were in use for almost 100 years; thus, it is understandable that recovery will take many years. Further, despite the absence of flowing water, we observed continued visitation of the capped well sites by elk (S. Garza, personal observation), and the resulting disturbance from trampling will further delay habitat community recovery. Ultimately, these combined observations suggest that recovery of well sites may be a function of annual precipitation and the rate of decreased use (i.e., disturbance) by ungulates.

\section{ACKNOWLEDGMENTS}

The study was funded by a cooperative effort between the U.S. Geological Survey (USGS), Colorado State University (CSU), and the NPS. Additional funds came from the Alliance for Graduate Education and the Professoriate and the Department of Fish, Wildlife, and Conservation Biology at CSU. Help was provided by USGS personnel, and we thank J. Kershner with the Northern Rocky Mountain Science Center for his guidance and K. Schoenecker with the Fort Collins Science Center for inspiring the project. J. Harte of the NPS provided valuable insight into the legal history of the groundwater rights of the San Luis Valley. J. Stevens with the Colorado Natural Heritage Program provided information on plant inventories. We also thank GRSA superintendents A. Hutchinson and L. Carrico and NPS employees A. Valdez, F. Bunch, and P. BovinPineda for project support.

\section{Literature Cited}

AKAIKe, H. 1973. Maximum likelihood identification of gaussian autoregressive moving average models. Biometrika 60:255-265. 
ANDREW, M.H. 1988. Grazing impact in relation to livestock watering points. Trends in Ecology and Evolution 3:336-339.

ANDREW, M.H., AND R.T. LANGE. 1986. Development of a new piosphere in arid chenopod shrubland grazed by sheep. Australian Journal of Ecology 11:411-424.

Augustine, D.J., D.T. Boоth, S.E. Cox, And J.D. DERNER. 2012. Grazing intensity and spatial heterogeneity in bare soil in a grazing-resistant grassland. Rangeland Ecology and Management 65:39-46.

Brooks, M.L., J.R. Matchett, and K.H. Berry. 2006. Effects of livestock watering sites on alien and native plants in the Mojave Desert, USA. Journal of Arid Environments 67:125-147.

Burnham, K.P., And D.R. Anderson. 2002. Model selection and multimodel inference: a practical information-theoretic approach. 2nd edition. Springer New York, NY.

Cayan, D.R., T. Dasa, D.W. Pierce, T.P. Barnetta, M. Tyree, and A. Gershunov. 2010. Future dryness in the southwest U.S. and the hydrology of the early 21st century drought. Proceedings of the National Academy of Sciences 107:21271-21276.

DaubenmiRe, R.F. 1975. Plant succession on abandoned fields and fire influences in a steppe area in southeastern Washington. Northwest Science 49:36-48.

Fernandez-Gimenez, M., and B. Allen-Diaz. 2001. Vegetation change along gradients from water sources in three grazed Mongolian ecosystems. Plant Ecology 157:101-118.

Fusco, M., J. Holechek, A. Tembo, A. Daniel, and M. CARDENAS. 1995. Grazing influences on watering point vegetation in the Chihuahuan desert. Journal of Range Management 48:32-38.

Golodets, C., J. Kigel, And M. Sternberg. 2010. Recovery of plant species composition and ecosystem function after cessation of grazing in a Mediterranean grassland. Plant and Soil 329:365-378.

Gutman, M., and N.G. Seligman. 1979. Grazing management of Mediterranean foothill range in the Upper Jordan River Valley. Journal of Range Management 32:86-92.

HiLL, M.O. 1973. Diversity and evenness: a unifying notation and its consequences. Ecology 54:427-432.

Hosten, P., AND N. West. 1994. Cheatgrass dynamics following wildfire on a sagebrush semidesert site in central Utah. Pages 56-62 in S.B. Monsen and S.G. Kitchen, compilers, Proceedings-ecology and management of annual rangelands. INT-GTR-313, USDA Forest Service, Ogden, UT.

Hurvich, C.M., and C.L. Tsai. 1989. Regression and time series model selection in small samples. Biometrika 76:297-307.

James, C.D., J. Landsberg, and S.R. Morton. 1997. Provision of watering points in the Australian arid zone: a review of effects on biota. Journal of Arid Environments 41:87-121.

Kotanen, P.M. 1997. Effects of experimental soil disturbance on revegetation by natives and exotics in coastal Californian meadows. Journal of Applied Ecology 34:631-644.

Landsberg, J., C.D. James, S.R. Morton, W.J. Müller, and J. STOL. 2003. Abundance and composition of plant species along grazing gradients in Australian rangelands. Journal of Applied Ecology 40:1008-1024.

LANGE, R.T. 1969. The piosphere: sheep track and dung patterns. Journal of Range Management 22:396-400.
LONSDALE, W.M. 1999. Global patterns of plant invasions and the concept of invasibility. Ecology 80 : 1522-1536.

Mack, R.N., AND J.N. Thompson. 1982. Evolution in steppe with few large, hooved mammals. American Naturalist 119:757-773.

Marin, L., S.L. Forman, A. Valdez, and F. Bunch. 2005. Twentieth century dune migration at the Great Sand Dunes National Park and Preserve, Colorado, relation to drought variability. Geomorphology 70: $163-183$.

Marushia, R.G., M.L. Brooks, and J.S. Holt. 2012. Phenology, growth, and fecundity as determinants of distribution in closely related nonnative taxa. Invasive Plant Science and Management 5:217-229.

Milchunas, D.G. 2011. Plant community dynamics in shortgrass steppe with grazing relaxation and imposition by large and small herbivores. Israel Journal of Ecology and Evolution 57:23-41.

NANGULA, S., AND G. OBa. 2004. Effects of artificial water points on the Oshana ecosystem in Namibia. Environmental Conservation 31:47-54.

Nash, M.S., W.G. Whitford, A.G. De Soyza, J.W. Van ZEe, AND K.M. HavsTad. 1999. Livestock activity and Chihuahuan desert annual-plant communities: boundary analysis of disturbance gradients. Ecological Applications 9:814-823.

Perry, L.G., P.B. Shafroth, D.M. Blumenthal, J.A. Morgan, and D.R. Lecain. 2013. Elevated $\mathrm{CO}_{2}$ does not offset greater water stress predicted under climate change for native and exotic riparian plants. New Phytologist 197:532-543.

Rigge, M., A. Smart, and B. Wylie. 2013. Optimal placement of off-stream water sources for ephemeral stream recovery. Rangeland Ecology and Management 66: 479-486.

RickaRd, W.H., AND R.H. SAuER. 1982. Self-revegetation of disturbed ground in deserts of Nevada and Washington. Northwest Science 56:41-47.

Riginos, C., AND M. Hoffman. 2003. Changes in population biology of two succulent shrubs along a grazing gradient. Journal of Applied Ecology 40:615-625.

SCHOENECKER, K.A. 2012. Ecology of bison, elk, and vegetation in an arid ecosystem. Doctoral dissertation, Colorado State University, Fort Collins, CO. 104 pp.

Spackman Panjabi, S., K. Decker, G. Doyle, and D.G. Anderson. 2004. Great Sand Dunes National Monument and Preserve 2003 vascular plant inventory. Report prepared for the National Park Service by the Colorado Natural Heritage Program.

Stohlgren, T.J. 2007. Measuring plant diversity: lessons from the field. Oxford University Press, Oxford.

SwIFT, L.W. 1945. A partial history of the elk herds of Colorado. Journal of Mammalogy 26:114-119.

ToDD, S.W. 2006. Gradients in vegetation cover, structure, and species richness of nama-karoo shrublands in relation to distance from livestock watering points. Journal of Applied Ecology 43:293-304.

Tolsma, D.J., W. ERnst, and R.A. Verwey. 1987. Nutrients in soil and vegetation around 2 artificial water points in eastern Botswana. Journal of Applied Ecology 24:991-1000.

Received 24 January 2014 Accepted 25 July 2014 